\title{
Relation between skin tests, inhalation tests, and histamine release from leucocytes and IgE in house-dust mite allergy
}

\author{
K. F. KERREBIJN, H. J. DEGENHART, and A. HAMMERS \\ From the Department of Paediatrics, Erasmus University, and Sophia Children's Hospital, Rotterdam, The \\ Netherlands
}

\begin{abstract}
Kerrebijn, K. F., Degenhart, H. J., and Hammers, A. (1976). Archives of Disease in Childhood, 51, 252. Relation between skin tests, inhalation tests, and histamine release from leucocytes and IgE in house-dust mite allergy. This study was concerned with the correlation between skin test, bronchial provocation test, and histamine release from leucocytes and the serum level of total and allergenspecific IgE in patients atopic to house-dust mite allergen (Dermatophagoides pteronyssinus) as measured by an intracutaneous skin test. It is concluded that, assuming a positive provocation test to be evidence of allergy, estimation of the allergen-specific IgE concentration in the serum will not offer any major advantages over the intradermal skin test in determining the clinical significance of house-dust mite allergy.
\end{abstract}

Of the factors which play a role in triggering an asthmatic response, hypersensitivity to inhalant allergens is important. This probably consists of both a nonspecific component in which complement plays a role (Berrens, 1974), and a specific component mainly based on a type 1 sensitivity reaction (Coombs, 1968), though a type 3-like reaction may also be important (Booij-Noord et al., 1972). The reaction of allergen with antibody molecules present on the cell membranes of mast cells, basophils, and other leucocytes will produce a chain of intracellular enzyme reactions, resulting in the release of histamine and other vasoactive amines which cause obstruction of the bronchi due to swelling of the mucosa and spasm of smooth muscle tissues. However, histamine can be released in nonspecific reactions as well. The presence of specific IgE antibodies to allergens (reagins) suggests that inhalation of these allergens may result in bronchial obstruction.

There are various methods besides the skin test to detect the presence of reagins, qualitatively or quantitatively in serum (Wide, Bennich, and Johansson, 1967; Coombs et al., 1968). Bronchial obstruction occurs after provocation with allergen when the allergen-specific IgE subfractions are biologically active. This can be investigated in-

Received 14 July 1975. directly by means of a test in which the allergen is inhaled through an aqueous aerosol. Three types of response can be differentiated (Van Lookeren Campagne, Knol, and de Vries, 1969). (1) Bronchial obstruction occurring during or immediately after exposure to the allergen. (2) Delayed bronchial obstruction occurring within 6-12 hours of exposure. (3) An immediate reaction followed by a delayed reaction. When allergen is added to a suspension of leucocytes from a patient with IgE antibodies to this allergen, histamine will be released (Ishizaka et al., 1969; Lichenstein, Levy and Ishizaka, 1970). Approximately $50 \%$ of this histamine comes from basophils, the other $50 \%$ from eosinophils and neutrophils (Lichenstein and Norman, 1969).

The present study was concerned with the correlation between skin test, bronchial provocation test, and histamine release from leucocytes and the serum level of total and allergen-specific IgE in patients atopic to house-dust mite allergen (Dermatophagoides pteronyssinus) as measured by an intracutaneous skin test.

\section{Methods}

Twenty asthmatic children 8-12 years of age were studied. The children were not desensitized and did not take any drugs during the investigation. 
Concentration of allergen. The water-soluble fraction of house-dust mite (D. pteronyssinus) allergen was prepared as follows. $500 \mathrm{mg}$ mites were suspended in $250 \mathrm{ml} 0.1 \mathrm{mmol} / 1$ phosphate buffer, $p H 6.8$, and stirred at room temperature for 2 hours. The insoluble material was removed by filtration (G-5 glass filter) and the resulting clear solution immediately lyophilized. This preparation was stored at $-20^{\circ} \mathrm{C}$. All allergen concentrations were freshly prepared from lyophilized material on the morning of the test and all tests were done with the same allergen solution in every subject. Blood samples, in which histamine release and IgE were determined, were taken on 3 consecutive days just before the provocation test.

Skin tests were performed with allergen concentrations of $1000,100,10$, and $1 \mu \mathrm{g} / \mathrm{ml}$. The initial concentration at bronchial provocation was $100 \mu \mathrm{g} / \mathrm{ml}$. When this failed to induce an immediate response, the test was repeated 7 days later with $1000 \mu \mathrm{g} / \mathrm{ml}$. A total of 29 provocation tests were performed in the 20 patients under investigation. Histamine release from leucocytes was measured with allergen concentrations of 1000 and $100 \mu \mathrm{g} / \mathrm{ml}$.

Histamine release test. The amount of histamine released from $1 \mathrm{ml}$ of a leucocyte suspension was determined after incubation with an allergen solution for 60 minutes using the method described by May, Lyman, and Alberto (1970). Total histamine content was not determined by direct butanol extraction, but by extraction after 30 minutes' incubation in a boiling waterbath. All tests were performed in triplicate and each result is the average of three tests. The basal histamine release due to the test procedure was also determined and a correction therefore was made. As there is a linear relation between the concentration of leucocytes and the absolute histamine release, and as the concentration of leucocytes cannot be standardized, histamine release is not stated in absolute amounts but in percentages of the maximum histamine release.

Allergen-specific IgE. It was essential that a similar allergen be used in all tests. Instead of using the commercially available house-dust Phadebas kit, the concentration of allergen-specific IgE in the serum was therefore measured in the following way. The total amount of IgE was determined using the total IgE Phadebas kit. Allergen was then linked to glass pearls. After incubation of the allergen carrier complex with the patient's serum, the IgE bound to allergen was

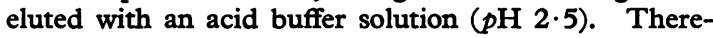
after the $\operatorname{IgE}$ in the eluate was estimated using the total-IgE Phadebas kit (Degenhart et al., in preparation).

Bronchial provocation. On the morning of the day before testing the vital capacity (VC) and the forced expiratory volume in one second $\left(\mathrm{FEV}_{1}\right)$ were determined before and after inhalation of the solvent for 10 minutes. Pulmonary function was recorded with a Lode spirometer No. D 53. The nebulizer used was the Doppel-inhalator (made by Blümel, Wiesbaden) with an airflow of $8 \mathrm{l} / \mathrm{min}$. Pulmonary function was determined before, immediately after and 1,8 , and 24 hours after inhalation of allergen. All provocation tests were performed during a clinically optimal period in hospital. The initial $\mathrm{FEV}_{1} / \mathrm{VC}$ value was $55 \%$ in 2 inhalation tests, $60-70 \%$ in 4 , and $71 \%$ or more in 23 . The provocation test was regarded as positive when the $\mathrm{VC}$ or $\mathrm{FEV}_{1}$ were reduced by more than $15 \%$ of the initial level, and doubtfully positive when the reduction varied from $10-15 \%$. Bronchial hyper-reactivity (de Vries, 1970) was not measured but the histamine threshold was $8 \mathrm{mg} / \mathrm{ml}$ or more in at least 2 tests in every case.

Skin tests. These were performed intradermally on the volar surface of the forearm using four concentrations of allergen.

\section{Results}

Histamine release. The accuracy of the histamine concentration measurements was checked by carrying out 10 determinations in duplicate at each of the concentrations of $20,30,40,50$, and $60 \mu \mathrm{g} / \mathrm{l}$. The standard deviation of the single determination was $4.5 \%$ in the $20-60 \mu \mathrm{g} / 1$ range. Table I shows the $\mathrm{SD}$ and the standard error of the mean in the range of a low to a marked histamine release. The reproducibility on various days was examined in 23 asthmatic children with a

TABLE I

Accuracy of estimations of histamine release (HR)

\begin{tabular}{|c|c|c|c|c|}
\hline $\begin{array}{l}\text { Histamine release in } \\
\% \text { of maximum HR }\end{array}$ & No. of estimations & $\begin{array}{l}\text { Mean histamine release } \\
\text { in } \% \text { of maximum HR }\end{array}$ & SD & SEM \\
\hline $\begin{array}{c}0-9 \\
10-19 \\
20-29 \\
30-39 \\
40-49 \\
50-59 \\
60-69 \\
\geqslant 70\end{array}$ & $\begin{array}{l}30 \\
26 \\
20 \\
22 \\
36 \\
46 \\
40 \\
12\end{array}$ & $\begin{array}{r}5 \\
15 \\
26 \\
36 \\
45 \\
55 \\
65 \\
81\end{array}$ & $\begin{array}{l}3 \\
5 \\
4 \\
5 \\
5 \\
7 \\
6 \\
7\end{array}$ & $\begin{array}{l}0 \cdot 6 \\
1 \cdot 0 \\
0 \cdot 8 \\
1 \cdot 0 \\
0 \cdot 8 \\
1 \cdot 0 \\
1 \cdot 0 \\
2 \cdot 2\end{array}$ \\
\hline
\end{tabular}


positive skin test to house-dust allergen (Fig. 1.) Though the histamine release varies on different days, it is in the same order of magnitude in the majority of cases, i.e. it shows either a marked increase $(\geqslant 40 \%)$, a moderate increase $(20-39 \%)$, or a slight increase $(<20 \%)$. In 4 healthy controls provocation did not result in histamine release.

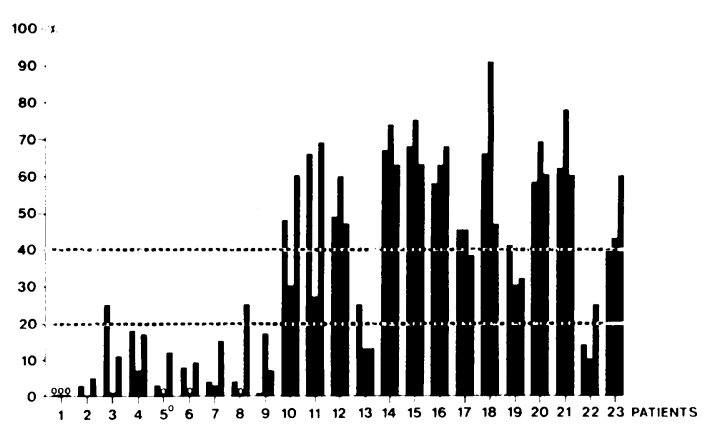

Fig. 1.-Histamine release (highest value in $\%$ of maximal histamine release) on different days, house mite allergen (Dermatophagoides pteronyssinus). Broken lines indicate marked, moderate, or slight release.

IgE. The accuracy and reproducibility of IgE measurements can be assessed from the calibration line in Fig. 2. This was composed of triplicate estimations at eight different IgE concentrations. The SD of the single determination of IgE was calculated from 36 duplicate determinations and is approximately 2 units $/ \mathrm{ml}$ in the $1-200$ units $/ \mathrm{ml}$ range. In this range the SD is independent of the $\operatorname{IgE}$ concentration. The linkage of IgE to allergen may be affected by factors in the

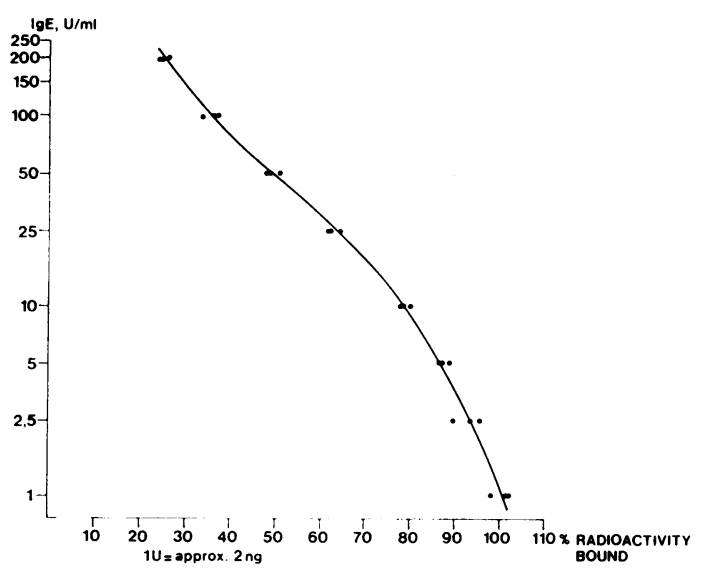

FIG. 2.-Standard curve of the IgE determination with the Phadebas-kit. serum, the nature of which is largely unknown (Aalberse, Reerink-Brongers, and Vermeulen, 1973).

The significance of these factors for the determination of allergen-specific IgE currently cannot be quantitated. It appears to be negligible, however, in the range of the IgE levels measured in the present study (Degenhart et al., in preparation).

Results of comparative studies. Tables II and III show the results obtained in 12 children with strongly positive skin tests ('skin titre' 10 or $1 \mu \mathrm{g} / \mathrm{ml}$ ), in 2 with moderately positive skin tests ('skin titre' $100 \mu \mathrm{g} / \mathrm{ml}$ ) and in 6 with negative skin tests to house mite allergen. The following is apparent from these two tables.

(1) A strongly positive intradermal skin test (10 or $1 \mu \mathrm{g} / \mathrm{ml}$ ) may be accompanied by marked or by moderate histamine release on leucocyte provocation.

(2) The three types of response to provocation may be associated with strongly positive skin tests.

(3) Histamine release is low and a positive response to provocation is absent when skin tests are negative.

(4) A good correlation exists between a positive provocation test and high histamine release $(\geqslant 40 \%)$ and vice versa. When the provocation test is negative, histamine release will be low. *

(5) The result of the provocation test (immediate with or without delayed response; not immediate but a delayed response) varies with the concentration of allergen used.

(6) An obvious relation exists between the mitespecific and total serum IgE concentration on the one hand and the skin titre, response to provocation, and magnitude of the histamine release on the other.

As the IgE level increases the skin titre will be more stongly positive, the provocation test will be positive more often, and histamine release will be higher. A definite relation exists between the concentration of specific IgE in the serum and the skin titre. The relation between the concentration of specific IgE in the serum and histamine release is less marked but present. The multiple regression coefficient is $0 \cdot 88$. The average concentration of allergen-specific $\operatorname{IgE}$ in the serum was $1 \mathrm{unit} / \mathrm{ml}$ in normal controls.

\footnotetext{
*Statistical analysis ( $\chi^{2}$ test) shows-(a) Provocation dose 100 $\mu \mathrm{g} / \mathrm{ml}$ : immediate response, $\chi^{2}=1.56$, NS; delayed response, $\chi^{2}=7 \cdot 21,0 \cdot 10>\mathrm{P}>0 \cdot 05$. (b) Provocation dose $1000 \mu \mathrm{g} / \mathrm{ml}$ : immediate response, $\chi^{2}=7.91,0.05>P>0.025$; delayed response, $\chi^{2}=13 \cdot 16,0 \cdot 005>P>0 \cdot 001$.
} 
TABLE II

Correlation of skin titre, leucocyte histamine release, provocation test, and serum IgE with house-dust mite extract (D. pteronyssinus)

\begin{tabular}{|c|c|c|c|c|c|c|c|c|c|c|c|}
\hline \multirow{4}{*}{ Case no. } & \multirow{4}{*}{$\begin{array}{l}\text { Lowest } \\
\text { concen- } \\
\text { tration } \\
\text { at which } \\
\text { skin } \\
\text { test was } \\
\text { positive } \\
(\mu \mathrm{g} / \mathrm{ml})\end{array}$} & \multirow{4}{*}{$\begin{array}{c}\text { Histamine } \\
\text { release } \\
\text { with } 100 \\
\text { or } 1000 \\
\mu \mathrm{g} / \mathrm{ml} \text { in } \\
\% \text { of maxi- } \\
\text { mum } \mathrm{HR}\end{array}$} & \multicolumn{6}{|c|}{ Provocation test } & \multicolumn{3}{|c|}{$\operatorname{IgE}$} \\
\hline & & & \multicolumn{3}{|c|}{$100 \mu \mathrm{g} / \mathrm{ml}$} & \multicolumn{3}{|c|}{$1000 \mu \mathrm{g} / \mathrm{ml}$} & \multirow{3}{*}{$\begin{array}{c}\text { Total } \\
\text { (units } / \mathrm{ml} \text { ) }\end{array}$} & \multicolumn{2}{|c|}{ Mite-specifict } \\
\hline & & & \multicolumn{3}{|c|}{ Response } & \multicolumn{3}{|c|}{ Response } & & \multirow{2}{*}{ (units/ml) } & \multirow{2}{*}{$\begin{array}{c}\% \text { of total } \\
\text { IgE }\end{array}$} \\
\hline & & & $\begin{array}{c}\text { Imme- } \\
\text { diate }\end{array}$ & $\begin{array}{l}\text { After } \\
8 \mathrm{~h}\end{array}$ & $\begin{array}{l}\text { After } \\
24 \mathrm{~h}\end{array}$ & $\begin{array}{l}\text { Imme- } \\
\text { diate }\end{array}$ & $\begin{array}{l}\text { After } \\
8 \mathrm{~h}\end{array}$ & $\begin{array}{l}\text { After } \\
24 \mathrm{~h}\end{array}$ & & & \\
\hline 1 & 1 & 75 & + & + & + & & & & 573 & 15 & $2 \cdot 6$ \\
\hline 2 & 10 & 73 & - & + & + & + & + & + & 1781 & 24 & $1 \cdot 3$ \\
\hline 3 & 1 & 69 & - & + & + & + & + & + & 1061 & 13 & $1 \cdot 2$ \\
\hline 4 & 1 & 60 & + & + & + & & & & 3990 & 36 & 0.9 \\
\hline 5 & 1 & 59 & - & + & + & + & + & + & 775 & 14 & $1 \cdot 8$ \\
\hline 6 & 10 & 59 & - & + & + & + & + & + & 260 & 9 & $3 \cdot 5$ \\
\hline 7 & 10 & 37 & - & - & - & - & - & - & 3752 & 28 & 0.7 \\
\hline 8 & 1 & 31 & + & + & + & & & & 688 & 15 & $2 \cdot 2$ \\
\hline 9 & 10 & 27 & - & + & + & \pm & - & - & 922 & 14 & 1.5 \\
\hline 11 & 10 & 25 & .. & - & - & \pm & - & - & 3976 & 33 & 0.8 \\
\hline 12 & 10 & 17 & 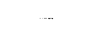 & + & + & + & + & + & 2145 & 18 & 0.8 \\
\hline 13 & 100 & 51 & - & - & - & - & + & + & 213 & 0 & 0 \\
\hline 14 & 100 & 19 & $\ldots$ & - & - & - & - & - & 210 & 5 & $2 \cdot 3$ \\
\hline 15 & Neg & 14 & - & - & - & - & - & - & 210 & 0 & 0 \\
\hline 16 & $\mathrm{Neg}$ & 3 & - & $\ldots$ & - & - & - & - & 130 & 0 & 0 \\
\hline 17 & $\mathrm{Neg}$ & 25 & - & - & - & - & - & - & 49 & 6 & $12 \cdot 2$ \\
\hline 18 & Neg & 18 & - & - & - & - & -- & - & 180 & 0 & 0 \\
\hline 19 & Neg & 3 & $\ldots$ & - & - & - & - & - & 42 & 0 & 0 \\
\hline 20 & Neg & 0 & - & - & - & - & - & - & 76 & 0 & 0 \\
\hline
\end{tabular}

$\star$ Highest of 3 estimations.

†Average of 3 estimations on 3 consecutive days.

1 unit = approximately 2 ng.

\section{Discussion}

In the present study the relation of the results of the skin test, provocation test, and histamine release from leucocytes and serum $\operatorname{IgE}$ concentration (total and allergen-specific) was examined. As house dust is believed to be among the most important inhalant allergens in the Netherlands and as the house-dust mite (D. pteronyssinus) was found to contribute to a considerable extent to the allergens in house dust (Voorhorst et al., 1967), the study was primarily concerned with mite allergen, though other investigators report the correlation of diagnostic procedures with regard to house dust allergy to be inferior to those of tests for other allergens (e.g. animal danders and pollen) (Berg, Bennich, and Johansson, 1971; Aas and Johansson, 1971).

The method used here to estimate specific IgE offers several advantages over the classic radioallergosorbent test (RAST) (Johansson, Bennich, and Wide, 1968), which is at present universally available using the Phadebas house-dust kit. However, in this study the comparative studies have been done with allergen of the same batch. Moreover, coated glass pearls used as carriers are more stable and their linkage to allergen is more rapid and satisfactory than that of normal carriers. An additional advantage of our method is that the concentration of specific IgE is determined in units of weight rather than in reference serum units. In comparing various tests, the following requirements should be met. (1) A potent allergen showing the highest possible degree of purity and originating from the same batch should be used in all tests. (2) All tests should be performed at the same time. (3) The tests should be performed during optimum clinical and physiological conditions. Drugs which may affect the results, such as corticosteroids, disodium cromoglycate, antihistamines, or bronchodilators, should not be administered during the tests. It should be stated whether patients have been desensitized.

All requirements were met in the present study. The results show that a high concentration of reagins in the skin (i.e. a positive skin test with a low allergen concentration) is invariably associated with an increased serum level of specific IgE. However, testing for IgE does not appear to be more sensitive than skin testing, as observed by Hogarth Scott in a number of cases (Hogarth- 
TABLE III

Correlation of provocation test, skin titre, serum IgE, and histamine release $(H R)$ with house-dust mite extract (D. pteronyssinus)

\begin{tabular}{|c|c|c|c|c|c|c|c|c|c|c|c|c|}
\hline \multirow{2}{*}{$\begin{array}{l}\text { Lowest } \\
\text { concentration } \\
\text { at which skin } \\
\text { test was } \\
\text { positive }\end{array}$} & \multirow{2}{*}{ No. } & \multicolumn{2}{|c|}{$\begin{array}{l}\text { Total IgE } \\
\text { (units/ml) }\end{array}$} & \multicolumn{3}{|c|}{$\begin{array}{l}\text { Specific IgE } \\
\text { (units } / \mathrm{ml} \text { ) }\end{array}$} & \multicolumn{3}{|c|}{ Provocation test } & \multicolumn{3}{|c|}{$\begin{array}{l}\text { Histamine release } \\
(\% \text { maximum HR) }\end{array}$} \\
\hline & & $\geqslant 500$ & $<500$ & $\geqslant 10$ & $1-9$ & 0 & $\begin{array}{l}\text { Posi- } \\
\text { tive }\end{array}$ & $\begin{array}{l}\text { Doubt- } \\
\text { ful* }\end{array}$ & $\begin{array}{l}\text { Nega- } \\
\text { tive }\end{array}$ & $\geqslant 40$ & $20-39$ & $<20$ \\
\hline $\begin{array}{l}1 \text { or } 10 \\
100 \text { or } 1000 \\
\text { Negative }\end{array}$ & $\begin{array}{r}12 \\
2 \\
6\end{array}$ & $\begin{array}{r}10 \\
0 \\
0\end{array}$ & $\begin{array}{l}2 \\
2 \\
6\end{array}$ & $\begin{array}{r}10 \\
0 \\
0\end{array}$ & $\begin{array}{l}2 \\
1 \\
1\end{array}$ & $\begin{array}{l}0 \\
1 \\
5\end{array}$ & $\begin{array}{l}8 \\
0 \\
0\end{array}$ & $\begin{array}{l}2 \\
1 \\
0\end{array}$ & $\begin{array}{l}2 \\
1 \\
6\end{array}$ & $\begin{array}{l}6 \\
1 \\
0\end{array}$ & $\begin{array}{l}5 \\
0 \\
1\end{array}$ & $\begin{array}{l}1 \\
1 \\
5\end{array}$ \\
\hline \multirow{2}{*}{ Provocation test } & \multirow{2}{*}{ No. } & \multicolumn{2}{|c|}{$\begin{array}{r}\text { Total IgE } \\
\text { (units/ml) }\end{array}$} & \multicolumn{3}{|c|}{$\begin{array}{l}\text { Specific IgE } \\
\text { (units } / \mathrm{ml} \text { ) }\end{array}$} & \multicolumn{3}{|c|}{$\begin{array}{c}\text { Lowest concentration } \\
\text { at which skin test was } \\
\text { positive }(\mu \mathrm{g} / \mathrm{ml})\end{array}$} & \multicolumn{3}{|c|}{$\begin{array}{l}\text { Histamine release } \\
(\% \text { maximum } \mathrm{HR})\end{array}$} \\
\hline & & $\geqslant 500$ & $<500$ & $\geqslant 10$ & $1-9$ & 0 & 1 or 10 & $\begin{array}{c}100 \\
\text { or } 1000\end{array}$ & $\begin{array}{l}\text { Nega- } \\
\text { tive }\end{array}$ & $\geqslant 40$ & $20-39$ & $<20$ \\
\hline $\begin{array}{l}\text { Positive } \\
\text { Doubtful` } \\
\text { Negative }\end{array}$ & $\begin{array}{l}8 \\
3 \\
9\end{array}$ & $\begin{array}{l}7 \\
1 \\
2\end{array}$ & $\begin{array}{l}1 \\
2 \\
7\end{array}$ & $\begin{array}{l}7 \\
1 \\
2\end{array}$ & $\begin{array}{l}1 \\
1 \\
2\end{array}$ & $\begin{array}{l}0 \\
1 \\
5\end{array}$ & $\begin{array}{l}8 \\
2 \\
2\end{array}$ & $\begin{array}{l}0 \\
1 \\
1\end{array}$ & $\begin{array}{l}0 \\
0 \\
6\end{array}$ & $\begin{array}{l}6 \\
1 \\
0\end{array}$ & $\begin{array}{l}1 \\
2 \\
3\end{array}$ & $\begin{array}{l}1 \\
0 \\
6\end{array}$ \\
\hline \multirow{2}{*}{$\begin{array}{l}\text { Specific IgE } \\
\text { (units } / \mathrm{ml} \text { ) }\end{array}$} & \multirow{2}{*}{ No. } & \multicolumn{2}{|c|}{$\begin{array}{l}\text { Total IgE } \\
\text { (units } / \mathrm{ml} \text { ) }\end{array}$} & \multicolumn{3}{|c|}{$\begin{array}{c}\text { Lowest concentration at } \\
\text { which skin test was } \\
\text { positive }(\mu \mathrm{g} / \mathrm{ml})\end{array}$} & \multicolumn{3}{|c|}{ Provocation test } & \multicolumn{3}{|c|}{$\begin{array}{l}\text { Histamine release } \\
(\% \text { maximum HR) }\end{array}$} \\
\hline & & $\geqslant 500$ & $<500$ & 1 or 10 & $\begin{array}{c}100 \\
\text { or } 1000\end{array}$ & $\begin{array}{l}\text { Nega- } \\
\text { tive }\end{array}$ & $\begin{array}{l}\text { Posi- } \\
\text { tive }\end{array}$ & $\begin{array}{l}\text { Doubt- } \\
\text { ful }\end{array}$ & $\begin{array}{l}\text { Nega- } \\
\text { tive }\end{array}$ & $\geqslant 40$ & $20-39$ & $<20$ \\
\hline $\begin{array}{l}\geqslant 10 \\
1-9 \\
0\end{array}$ & $\begin{array}{r}10 \\
4 \\
6\end{array}$ & $\begin{array}{r}10 \\
0 \\
0\end{array}$ & $\begin{array}{l}0 \\
4 \\
6\end{array}$ & $\begin{array}{r}10 \\
2 \\
0\end{array}$ & $\begin{array}{l}0 \\
1 \\
1\end{array}$ & $\begin{array}{l}0 \\
1 \\
5\end{array}$ & $\begin{array}{l}7 \\
1 \\
0\end{array}$ & $\begin{array}{l}1 \\
1 \\
1\end{array}$ & $\begin{array}{l}2 \\
2 \\
5\end{array}$ & $\begin{array}{l}5 \\
1 \\
1\end{array}$ & $\begin{array}{l}4 \\
2 \\
0\end{array}$ & $\begin{array}{l}1 \\
1 \\
5\end{array}$ \\
\hline \multirow{2}{*}{$\begin{array}{l}\text { Histamine release } \\
\text { (\% maximum } \mathrm{HR} \text { ) }\end{array}$} & \multirow[t]{2}{*}{ No. } & \multicolumn{2}{|c|}{$\begin{array}{l}\text { Total IgE } \\
\text { (units/ml) }\end{array}$} & \multicolumn{3}{|c|}{$\begin{array}{l}\text { Specific IgE } \\
\text { (units } / \mathrm{ml} \text { ) }\end{array}$} & \multicolumn{3}{|c|}{$\begin{array}{l}\text { Lowes concentration at } \\
\text { which skin test was } \\
\text { positive }(\mu \mathrm{g} / \mathrm{ml})\end{array}$} & \multicolumn{3}{|c|}{ Provocation test } \\
\hline & & $\geqslant 500$ & $<500$ & $\geqslant 10$ & $1-9$ & 0 & 1 or 10 & $\begin{array}{c}100 \\
\text { or } 1000\end{array}$ & $\begin{array}{l}\text { Nega- } \\
\text { tive }\end{array}$ & $\begin{array}{l}\text { Posi- } \\
\text { tive }\end{array}$ & $\begin{array}{c}\text { Doubt- } \\
\text { ful }\end{array}$ & $\begin{array}{l}\text { Nega- } \\
\text { tive }\end{array}$ \\
\hline $\begin{array}{l}\geqslant 40 \\
20-39 \\
<20\end{array}$ & $\begin{array}{l}7 \\
6 \\
7\end{array}$ & $\begin{array}{l}5 \\
4 \\
1\end{array}$ & $\begin{array}{l}2 \\
2 \\
6\end{array}$ & $\begin{array}{l}5 \\
4 \\
1\end{array}$ & $\begin{array}{l}1 \\
2 \\
1\end{array}$ & $\begin{array}{l}0 \\
0 \\
5\end{array}$ & $\begin{array}{l}6 \\
5 \\
1\end{array}$ & $\begin{array}{l}1 \\
0 \\
1\end{array}$ & $\begin{array}{l}0 \\
1 \\
5\end{array}$ & $\begin{array}{l}6 \\
2 \\
1\end{array}$ & $\begin{array}{l}1 \\
1 \\
0\end{array}$ & $\begin{array}{l}0 \\
3 \\
6\end{array}$ \\
\hline
\end{tabular}

$\star$ Doubtful, i.e. provocation with $1000 \mu \mathrm{g} / \mathrm{ml}$ is followed by a reduction of the VC and/or $\mathrm{FFV}_{1}$ by $10-15 \%$ within $60 \mathrm{minutes}$ or by $>15 \%$ after 8 or 24 hours.

1 unit = approximately 2 ng.

Scott et al., 1973). A positive skin test or an increased serum concentration of allergen-specific IgE does not imply, however, that inhalation of allergen will result in marked histamine release or in bronchial obstruction. This agrees with the findings reported by Van Lookeren Campagne et al. (1969) and Aas (1970).

Bronchial obstruction following provocation usually occurs in the event of marked histamine release. Provocation tests may also be positive when provocation results in moderate or low histamine release. Histamine release following provocation is found to decrease as nonspecific histamine release increases (Fig. 3). If the effect of provocation is expressed by the total amount of histamine released spontaneously and after provocation, the relation between the two tests is maintained and provocation may result in bronchial obstruction while total histamine release is low.

De Vries (1970) noted that the initial pulmonary function and the histamine threshold (which may be regarded as a parameter of the degree to which the bronchi are susceptible to aspecific stimuli) are dependent upon one another. With a diminished pulmonary function the result of provocation may therefore be positive due to nonspecific factors. For this reason every provocation test was preceded by inhalation with the solvent and provocation was only performed when the result of inhalation with solvent was negative. All patients were tested during a clinically quiet period in which their pulmonary function was optimal. In all provoca- 


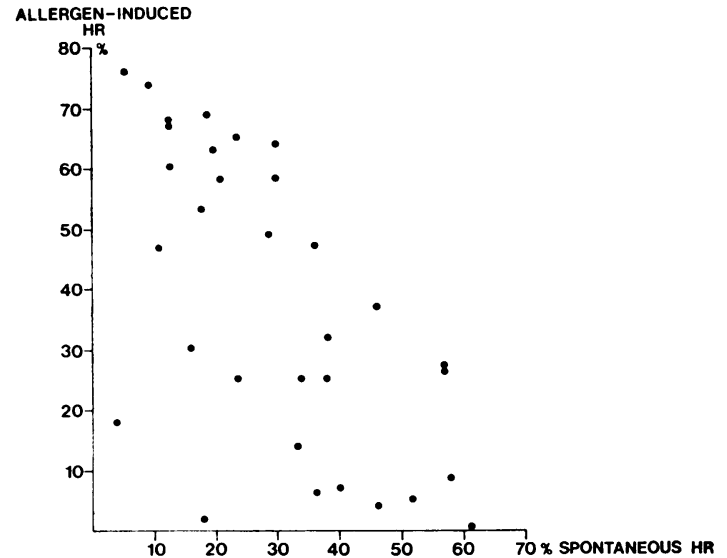

FIG. 3.-Relation between allergen-induced and spontaneous histamine release $(H R)$ in $\%$ of maximal histamine release.

tion tests but one in which the initial $\mathrm{FEV}_{1} / \mathrm{VC}$ value was $<70 \%$, there was no immediate response with $100 \mu \mathrm{g} / \mathrm{ml}$. A positive provocation test can therefore be considered to be due to an allergic reaction.

Aas and Johansson (1971) observed a correlation between the RAST and the provocation test with house-dust in $59 \%$ of the cases. Berg et al., (1971) observed identical results of RAST and provocation tests with various allergens in $74 \%$ of the cases. In these studies RAST and provocation tests were not performed at the same time and allergens of various batches were used. A study by Wide et al. (1971), which satisfied most of the criteria mentioned, showed that the results of 220 RAST and provocation tests with pollens, animal danders, and house-dust were similar in $95 \%$ of the cases. Foucard (1973) observed a correlation between a strongly positive prick test and a positive RAST in $86 \%$ of the cases. Miyamoto et al. (1974) studied the correlation between a high skin titre and the RAST and between the provocation test and the RAST with house-dust mite extract. Positive results correlated in $85 \%$ and negative results in $76.5 \%$ of the cases.

Our findings broadly agree with these results. When the skin test is negative, little if any specific IgE will be present in the serum and bronchial obstruction or histamine release after provocation will not be detectable to any appreciable extent.

\section{Conclusion}

Assuming a positive provocation test, performed during a period when the clinical and pulmonary physiological conditions are suitable, to be evidence of allergy, estimation of the allergen-specific IgE concentration in the serum will not offer any major advantages over the intradermal skin test (in which a 'skin titre' is determined by allergen dilutions) in determining the clinical significance of housedust mite allergy. The skin test has the advantages that it can be rapidly and readily performed and that it is cheap. Estimation of the IgE concentration has the advantage of causing less discomfort to the patient and of being easier to perform in longitudinal studies or mass screening. When the skin titre is 10 or $1 \mu \mathrm{g} / \mathrm{ml}$, or the serum specific IgE concentration is $>10$ units $/ \mathrm{ml}$ ( $>20 \mathrm{ng}$ ), the provocation test will very likely be positive in approximately $80 \%$ of patients. The histamine release test is not a suitable routine procedure as it is time consuming and technically difficult, but it is a useful reference test.

The present study was undertaken with the financial support of the Health Organization TNO and the Netherlands Asthma Fund. The authors are indebted to Dr. R. Voorhorst for making available the house-dust mite allergen.

\section{REFERENCES}

Aalberse, R. C., Reerink-Brongers, E. E., and Vermeulen, E. (1973). RAST-inhibiting factors in human serum. International Archives of Allergy and Applied Immunology, 45, 46.

Aas, K. (1970). Bronchial provocation tests in asthma. Archives of Disease in Childhood, 45, 221.

Aas, K., and Johansson, S. G. O. (1971). The radioallergosorbent test in the in vitro diagnosis of multiple reaginic allergy. A comparison of diagnostic approaches. Fournal of Allergy, 48, 134.

Berg, T., Bennich, H., and Johansson, S. G. O. (1971). In vitro diagnosis of atopic allergy. I. Comparison between provocation tests and the radio allergosorbent test. International Archives of Allergy and Applied Immunology, 40, 770.

Berrens, L. (1974). Inhalant allergens in human atopic disease: their chemistry and modes of action. Annals of the New York Academy of Sciences, 221, 183.

Booij-Noord, H., de Vries, K., Sluiter, H. J., and Orie, N. G. M. (1972). Late bronchial obstructive reaction to experimental inhalation of house-dust extract. Clinical Allergy, 2, 43.

Coombs, R. R. A. (1968). Immunopathology. British Medical Fournal, $1,597$.

Coombs, R. R. A., Hunter, A., Jonas, W. E., Bennich, H., Johansson, S. G. O., and Panzani, R., (1968). Detection of IgE (IgND) specific antibody (probably reagin) to castor-bean allergen by the red-cell-linked antigen-antiglobulin. Lancet, 1, 1115.

Foucard, T. (1973). A follow-up study of children with asthmatoid bronchitis. I. Skin test reactions and $I g E$ antibodies to common allergens. Acta Paediatrica Scandinavica, 62, 633.

Hogarth-Scott, R. S., McNicol, R. N., Williams, H. E., and Johansson, S. G. O. (1973). Diagnosis of allergy in vitro. A comparison between skin sensitivity testing and serum levels of specific IgE antibody in children. Medical fournal of Australia, $1,1293$.

Ishizaka, T., Ishizaka, K., Johansson, S. G. O., and Bennich, H. J. (1969). Histamine release from human leukocytes by anti IgE antibodies. Fournal of Immunology, 102, 884 .

Johansson, S. G. O., Bennich, H. and Wide, L. (1968). New class of immunoglobulin in human serum. Immunology, 14, 265.

Lichtenstein, L. M., and Norman, P. S. (1969). Human allergic reactions. American fournal of Medicine, 46, 163. 
Lichtenstein, L. M., Levy, D. A., and Ishizaka, K. (1970). In vitro reversed anaphylaxis: characteristics of anti-IgE mediated histamine release. Immunology, 19, 831.

van Lookeren Campagne, J.-G., Knol, K., and de Vries, K. (1969). House dust provocation in children. Scandinavian fournal of Respiratory Diseases, 50, 76.

May, C. D., Lyman, M., and Alberto, R. (1970). Procedures for immunochemical study of histamine release from leukocytes with small volume of blood. Fournal of Allergy, 46, 12.

Miyamoto, T., Johansson, S. G. O., Ito, K., and Horiuchi, Y. (1974). Atopic allergy in Japanese subjects: studies primarily with radioallergosorbent test. Fournal of Allergy and Clinical Immunology, 53, 9.

Voorhorst, R., Spieksma, F. Th. M., Varekamp, H., Leupen, M. J., and Lyklema, A. W. (1967). The house-dust mite (Dermatophagoides pteronyssinus) and the allergens it produces. Identity with the house-dust allergen. Fournal of Allergy, 39, 325. de Vries, K. (1970). Histamine thresholds and initial lung function values. Bronchitis III.. p. 359 . Ed. by N. G. M. Orie and R. van der Lende. Royal Vangorcum, Assen.

Wide, L., Bennich, H., and Johansson, S. G. O. (1967). Diagnosis of allergy by an in vitro test for allergen antibodies. Lancet, 2,1105 .

Wide, L., Aronsson, T., Fagerberg, E., and Zetterström, O. (1971). Radioimmunoassay of allergen-specific IgE. Proceedings of the VIII European Congress of Allergology. International Congress Series no. 235, p. 85. Ed. by J. Charpin. Excerpta Medica, Amsterdam.

Correspondence to Dr. K. F. Kerrebijn, Sophia Children's Hospital, Gordelweg 160, Rotterdam, The Netherlands. 